\title{
POLAND'S ENERGY SECURITY IN THE CONTEXT OF EU ENVIRONMENTAL INITIATIVES
}

\author{
Liliia Khorishko'
}

\begin{abstract}
The current conditions of global development actualize the need for political actors to form a high level of energy security. It expands the state's ability to ensure the sustainability of economic development and the ability to withstand likely threats. The issue of energy security and sovereignty are key on the agenda of the EU, which seeks to implement a strategy of global leadership. The environmental modernization of the EU energy sector and each member state must comply with the main goal of «The European Green Deal», which is to reduce carbon emissions by $55 \%$ before 2030 . The subject of the study is the substance and peculiarities of the formation of energy security in Poland. The aim of the study is to analyze the mechanisms of energy security of Poland in the context of EU environmental initiatives. Research methodology: systematic approach, method of analysis and comparison. The issue of energy security is recognized as key in achieving sustainable economic development in Poland. The content and basic principles of state energy security are presented in the National Security Strategy and detailed in the Energy Policy. Among the main directions of ecological modernization of the energy sector the following have been identified: efficient consumption of national energy resources; modernization of the energy sector and infrastructure; diversification of natural gas, oil, liquid fuel supplies; optimization of energy market functioning; construction of nuclear power plants; expansion of alternative energy sources; modernization of heating and co-generation energy systems; increasing energy efficiency. Polish officials have emphasized the need for a three-phase energy transition, involving a reduction in the production and use of coal, a gradual increase in the share of natural gas and the expansion of opportunities to use energy from alternative sources. The modernization of Poland's energy sector correlates with the implementation of «The European Green Deal» and other EU environmental initiatives. Energy sovereignty is secured through domestic and foreign financial assistance. The National Fund for Environmental Protection and Water Management of Poland attracts investments in environmental projects related to the development of geothermal energy and improvement of infrastructure energy efficiency. EU special funds (European Regional Development Fund/European Social Fund, Cohesion Fund, Just Transition Fund and Modernization Fund) provide funding for national or regional projects aimed at the comprehensive modernization of the Polish energy sector and the implementation of commitments to achieve climate neutrality. Poland pursues an active policy of cooperation in the energy sphere with other states - Denmark, Lithuania, Latvia, and Estonia. Projects such as "Baltic Pipe" and "The Baltic Synchronisation Project" are in the active implementation phase. The results of the study: energy security is a key factor in the sustainability of economic development of Poland, the implementation of the modernization of the national energy complex correlates with the EU environmental initiatives, which contributes to the attraction of domestic and foreign investment, as well as the resources of public diplomacy.
\end{abstract}

Key words: energy security, energy sovereignty, energy efficiency, environmental modernization, energy policy, climate neutrality.

JEL Classification: F52, Q42, Q48, Q54

\section{Introduction}

In the context of modern global development, energy security is an important component of national security of the state, its ability to withstand possible threats. The energy security of society is the key to sustainable economic development, as well as to increase the level of the state's subjectivity in the international political space. The issue of energy

\footnotetext{
Corresponding author:

${ }^{1}$ Zaporizhzhia National University, Ukraine.

E-mail: liliia_khorishko@ukr.net

ORCID: https://orcid.org/0000-0002-0618-976X
} 
security is key to the EU's global leadership strategy. In this context, EU institutions pay considerable attention to the conceptual and practical aspects of defining the basic principles of energy policy formation, involving the resource capacity of national governments in its implementation. At the same time, the issue of energy security is seen by EU leaders as an integral part of the implementation of the ambitious program "The European Green Deal", which provides for a reduction of carbon emissions by $55 \%$ until 2030, that is, to achieve climate neutrality. Against this background, member states face the challenge of implementing environmental modernization aimed at improving energy and resource efficiency and introducing "green technologies" to ensure sustainable economic development and resilience to the global challenges of our time.

The main purpose of the scientific exploration is to identify the peculiarities and to specify the mechanisms of Poland's energy security in the context of the EU's environmental initiatives. The state has had some success in achieving energy sovereignty, contributing to the sustainability of economic development and adapting to the challenges of our time. At the same time, the energy sector needs further modernization, which will help improve energy security and fulfill Poland's obligations to the EU to achieve climate neutrality. The complexity of the study lies in the disclosure of the main aspects of Poland's energy security and mechanisms of its implementation in the current political reality. The determination of the structural components of energy security and the level of their correlation with EU environmental initiatives will be facilitated by a systematic approach. The use of the comparative method will allow us to compare current and projected trends in the development of the energy sector in Poland. The method of analysis will help to clarify the essence of the state energy security, the main directions and mechanisms of implementation.

\section{Basic principles of Poland's energy security}

General aspects of energy security are defined in the National Security Strategy of Poland (National Security Strategy, 2020). In particular, we are talking about the use of traditional energy sources and the creation of opportunities for the development of alternative ones. Among the main objectives of government agencies are identified as follows: 1) expansion and modernization of production facilities in order to provide uninterrupted electricity supply; 2) diversification of sources and increase of capacities in oil and gas transportation; 3 ) continuation of diplomatic, legal, administrative efforts to restrain construction of transport infrastructure, which increases the dependence of the Central European region on Russian gas supplies.

These goals are synchronized with the content of the Energy Policy of Poland until 2040, aimed at increasing the level of energy security and competitiveness of the national economy, optimizing the use of resources, energy efficiency in the context of environmental protection. It is based on three areas - just transformation, a zero-emission energy system, and qualityair.Successfulimplementation ofthese directions is conditioned by achieving the following goals: 1) optimization of national energy resources use; 2) modernization of energy sector and infrastructure; 3) diversification of supplies and expansion of natural gas, oil and liquid fuel transportation infrastructure; 4) development of energy market; 5) construction of nuclear power plants; 6) development of alternative energy sources; 7) optimization of heating and cogeneration systems; 8) improvement of energy efficiency (Ministry of Climate and Environment of Poland, 2021). In this context, the government has defined certain indicators, the achievement of which will increase the level of energy security of the state and resilience to possible threats.

Analysis of the data in Table 1 confirms Poland's readiness to gradually reduce the use of coal both

Table 1

Current and projected indicators of the modernization level of Poland's energy sector

\begin{tabular}{|c|c|c|}
\hline Indicators & 2018 & 2030 \\
\hline Share of coal in electricity generation & $76 \%$ & $\geq 56 \%$ \\
\hline Share of renewable sources of energy in final consumption & $11,3 \%$ & $23 \%$ \\
\hline Share of renewable energy in transportation & $5,6 \%$ & $14 \%$ \\
\hline Carbon dioxide emissions & 300.5 million tons & $\geq 241$ million tons \\
\hline $\begin{array}{l}\text { Proportion of public transport (cars) with zero carbon emissions } \\
\text { in cities with populations over } 100,000\end{array}$ & $2 \%$ & $100 \%$ \\
\hline Number of free recharging points for electric vehicles & 900 & 49000 \\
\hline Amount of households using coal for heating. & $24,7 \%$ & $0 \%$ \\
\hline Number of households in cities connected to heating networks & 5,3 million & $+1,5$ million \\
\hline Quanttity of natural gas end users & 7,2 million & $+1,5$ million \\
\hline The level of energy poverty & $9,4 \%$ & $6 \%$ \\
\hline
\end{tabular}

Source: (Ministry of Climate and Environment of Poland, 2021) 
in electricity production and in heating individual households, through diversification and growth in the share of energy production from renewable sources. Significant attention will also be paid to reducing carbon emissions, especially in transportation, by shifting to electric vehicles and renewing the public transport fleet. The final result of the practical implementation of the Energy Policy's main principles should be a gradual transformation of the energy sector, modernization of key sectors of the national economy, achieving a high level of energy sovereignty.

This document also states that the formation of a national strategy in the energy sector is in line with the EU's key environmental initiatives. First, it is about the implementation of the program "The European Green Deal", aimed at reducing carbon emissions by $55 \%$ until 2030, as well as achieving climate neutrality. At the December EU summit, member states pledged to contribute to the goal based on sovereignty, justice and solidarity, taking into account the development of national economies. It should be noted that the Polish delegation supported the program "The European Green Deal", noting the need to take into account the historical development of state energy sector, its high level of focus on traditional energy sources, especially coal, requires a solidarity approach to cost sharing and collective responsibility for the implementation of lowcarbon energy transition.

Second, the implementation of the EU recommendations on climate and energy (2020-2030). They note the need to intensify low-carbon development of national economies in order to ensure energy sovereignty; reduce greenhouse gas emissions; and attract investment in the development of lowcarbon technologies. In this context, the following commitments of the EU member states are specified: 1) decarbonization of the energy sphere, while maintaining the sustainable development of national economies and energy sovereignty; 2) deepening of regional cooperation to coordinate efforts in addressing current climate and energy problems; 3 ) development of renewable energy sources; 4) strengthening energy security through integration of markets, diversification of imports, optimization of the use of traditional sources of energy, attracting investments in the development of the energy sector (Communication, 2014).

Third, the main goals and objectives of Poland's energy policy are synchronized with the Paris Climate Agreement (United Nations, 2015). They are aimed at reducing the rate of global warming, developing low-carbon technologies, and optimizing funding for climate change programs and projects. Those who agree voluntarily commit themselves to "nationally determined participation," defining each state's contribution to the fight against global warming. Consequently, the main goals and objectives of Poland's energy policy concretize the level of its environmental responsibility and readiness to cooperate in solving the global pressing problems of our time.

\section{Mechanisms to ensure energy security in Poland}

Poland's ruling elite focuses the attention of EU leaders on the need to consider the following factors of influence on the national economy: 1) the current level of dependence of the fuel and energy complex on traditional sources; 2) the planned three-phase energy transition, which provides for a reduction in coal consumption, while increasing the share of gas, the construction of nuclear power plants, the development of renewable energy; 3) projected increases in energy costs, which could affect the welfare of the population; 4) the effects of the economic crisis caused by the COVID-19 pandemic. Consequently, the pace of the low-carbon energy transition depends heavily on domestic and foreign investment. According to officials' calculations, in 2021-2040 ecological modernization of Polish economy requires investments of about 1600 billion zlotys, out of which - 867-890 billion requires fuel and energy complex, and 320-342 billion are necessary for construction of nuclear power plants and development of renewable energy (Ministry of Climate and Environment of Poland, 2021).

A large part of the cost of implementing a comprehensive modernization of the energy sector will come from special EU funds. The European Commission has approved the allocation of funding to member states for the years 2021-2027 as part of the Cohesion Policy implementation (European Council, 2021). Its main goal is to ensure economic, territorial and social consolidation of the $\mathrm{EU}$, to reduce disparities in the development of states and regions, as well as to support national economies in the implementation of ecological modernization. According to the approved plan, Poland receives financing from several funds (see Table 2).

Table 2

Financing of Poland by EU funds for 2021-2027

\begin{tabular}{|l|c|}
\hline \multicolumn{1}{|c|}{ Fund name } & $\begin{array}{c}\text { Planned funding, } \\
\text { million euros }\end{array}$ \\
\hline $\begin{array}{l}\text { European Regional Development } \\
\text { Fund / European Social Fund }\end{array}$ & 62.329 .8 \\
\hline Cohesion Fund & 9.283 .1 \\
\hline Just Transition Fund & 3.847 .4 \\
\hline
\end{tabular}

Source: European Council (2021)

It should be noted that financial assistance from the European Regional Development Fund / European Social Fund can be partially directed to projects related to the modernization of the energy sector, 
for example, within the framework of cross-border cooperation. The Cohesion Fund directs funding to national projects related to achieving climate neutrality. The Just Transition Fund finances environmental initiatives and projects in regions with a high level of dependence on traditional energy sources. Its main goal is to create the necessary conditions for a gradual transition to "green" technologies, modernizing national economies in order to minimize the negative socio-economic effects on the population of achieving carbon neutrality.

In addition, the EU created the Modernization Fund to provide special financial support to 10 member states, including Poland. Its main goal is to create the necessary opportunities and minimize the possible negative effects of national economies in the transition to carbon neutrality through the modernization of energy systems and the implementation of energy efficiency programs. It should be noted that Poland will receive $43 \%$ of the total amount of funding, given the high level of dependence on traditional sources of energy production (European Council, 2021). The Polish government also plans to cooperate with the Industrial Energy Conversion Fund, which provides grant funding for industrial projects aimed at ensuring energy efficiency and reducing carbon emissions.

The main internal mechanism for financing the modernization of Poland's energy sector is the National Fund for Environmental Protection and Water Management (Action Strategy, 2012). Priority areas for investment include modernizing municipal heating systems, developing geothermal energy, increasing the efficiency of power generation at small hydropower plants, and optimizing city infrastructure in the context of energy efficiency.

In addition to these funding mechanisms, the resources of public diplomacy are actively used to intensify mutually beneficial cooperation in the energy sphere with other states. Poland and Denmark are implementing the "Baltic Pipe" project aimed at building infrastructure for the transportation of Norwegian natural gas (Ministry of Climate and Environment of Poland, 2021). Its successful implementation will improve the competitiveness of gas prices in the European market as a whole, and
Poland will get an additional source of gas supplies, which will allow the realization of the three-phase energy transition program and reduce the level of economic dependence on Russian gas supplies.

The Executive Agency for Innovation and Networks has signed a grant agreement of 719,700,000 euros for the implementation of "The Baltic Synchronisation Project" involving Poland, Estonia, Latvia and Lithuania. (Innovation and Networks Executive Agency, 2020). The main goal of the project is to synchronize the power grids of the Baltic countries with continental Europe. It is planned to build the so-called "Harmony Link" across the Baltic Sea between Poland and Lithuania, which will become the basis for the formation of a renewable energy system. They will ensure the energy sustainability of the entire region and enhance the ability of participating states to implement "The European Green Deal".

\section{Conclusions}

The issue of energy security is relevant in ensuring the sustainability of Poland's economic development and ability to respond to the challenges of the global environment. The basic principles of state energy security are outlined in the National Security Strategy and the Energy Policy. As a member of the EU, Poland has committed itself to achieving climate neutrality by 2050 . In this context, a threephase energy transition aimed at minimizing the extraction of fossil fuels and then maximizing the use of natural gas and renewable energy sources to ensure the functioning of production facilities and meet the needs of citizens is envisaged. The modernization of Poland's energy sector correlates with the implementation of "The European Green Deal" and other EU environmental initiatives..

The state is focused on internal (National Fund for Environmental Protection and Water Management) and external (EU special funds) mechanisms to ensure energy sovereignty. These funds provide financing for national or regional projects aimed at the environmental modernization of Poland's energy sector. Significant attention is paid by state authorities to partnering with other entities to address pressing issues of energy sovereignty and sustainable economic development.

\section{References:}

Innovation and Networks Executive Agency (2020). INEA signs €720 million grant agreement for the Baltic Synchronisation project. Available at: https://ec.europa.eu/inea/en/news-events/newsroom/inea-signs720-million-grant-agreement-baltic-synchronisation-project (accessed 23 July 2021).

National Fund for Environmental Protection and Water Management (2012). Action Strategy of the National Fund for Environmental Protection and Water Management for 2013-2016 with a view to 2020. Available at: http://nfosigw.gov.pl/en/nfepwm/strategy/ (accessed 27 July 2021).

National Security Strategy of the Republic of Poland (2020). Available at: https://www.bbn.gov.pl/ftp/ dokumenty/Strategia_Bezpieczenstwa_Narodowego_RP_2020.pdf (accessed 23 July 2021). 
Communication from the Commission to the European parliament, the Council, the European economic and social Committee and the Committee of the regions (2014). A policy framework for climate and energy in the period from 2020 to 2030 . Available at: https://eur-lex.europa.eu/legal-content/EN/TXT/PDF/?uri= CELEX:52014DC0015\&from=EN (accessed 23 July 2021).

European Council (2021). Cohesion Policy 2021-2027. Available at: https://ec.europa.eu/regional_policy/ en/2021_2027/ (accessed 23 July 2021).

European Council (2021). 2021-2027 Cohesion policy EU budget allocations. Available at: https://cohesiondata.ec.europa.eu/stories/s/2021-2027-EU-allocations-available-for-programming/2w8s-ci3y/ (accessed 23 July 2021).

European Council (2021). Modernisation Fund. Available at: https://ec.europa.eu/clima/policies/budget/ modernisation-fund_en (accessed 27 July 2021).

Ministry of Climate and Environment of Poland (2021). Energy policy of Poland until 2040. Available at: https://www.gov.pl/web/klimat/polityka-energetyczna-polski-do-2040-r-przyjeta-przez-rade-ministrow (accessed 23 July 2021).

United Nations (2015). The Paris Agreement. Available at: https://unfccc.int/process-and-meetings/the-parisagreement/the-paris-agreement (accessed 29 July 2021). 